\title{
An Archaeological Survey of Converse City Park, Bexar County, Texas
}

Ralph Snavely

Follow this and additional works at: https://scholarworks.sfasu.edu/ita

Part of the American Material Culture Commons, Archaeological Anthropology Commons, Environmental Studies Commons, Other American Studies Commons, Other Arts and Humanities Commons, Other History of Art, Architecture, and Archaeology Commons, and the United States History Commons

Tell us how this article helped you.

This Article is brought to you for free and open access by the Center for Regional Heritage Research at SFA ScholarWorks. It has been accepted for inclusion in Index of Texas Archaeology: Open Access Gray Literature from the Lone Star State by an authorized editor of SFA ScholarWorks. For more information, please contact cdsscholarworks@sfasu.edu. 


\section{An Archaeological Survey of Converse City Park, Bexar County, Texas}

Creative Commons License

(c) (i) (8)

This work is licensed under a Creative Commons Attribution-NonCommercial 4.0 International License 


\section{AN ARCHAEOLOGICAL SURVEY OF CONVERSE CITY PARK, BEXAR COUNTY, TEXAS}

\section{RaTph Snavely}

Center for Archaeological Research The University of Texas at San Antonio Archaeological Survey Report, No. 166 





\section{AN ARCHAEOLOGICAL SURVEY OF CONVERSE CITY PARK, BEXAR COUNTY, TEXAS}

\section{Ralph Snavely}

Center for Archaeological Research The University of Texas at San Antonio ${ }^{\circledR}$ Archaeological Survey Report, No. 166 
A 1 ist of publications offered by the Center for Archaeological Research can be obtained by sending $\$ 1.00$ to the Center for Archaeological Research, The University of Texas at San Antonio, San Antonio, Texas 78285-0658. 


\section{ABSTRACT}

On March 3-4, 1986, the Center for Archaeological Research (CAR), The University of Texas at San Antonio (UTSA), conducted a survey of approximately 25 acres, comprising the Converse City Park on the south edge of Converse in Bexar County, Texas. The survey was required to comply with federal regulations. One area within the development zone was found to have a 1 ight surface scatter of cultural materials. This 1 ithic scatter was recorded and assigned a permanent state site designation (41 BX 698). An intensive search of the site area failed to produce any concentration of cultural materials other than the one area. No diagnostic tool types were observed. The cultural resources potential significance located within the survey area were not determined to be eligible for nomination to the National Register of Historic Places. No further work is recommended. 
TABLE OF CONTENTS

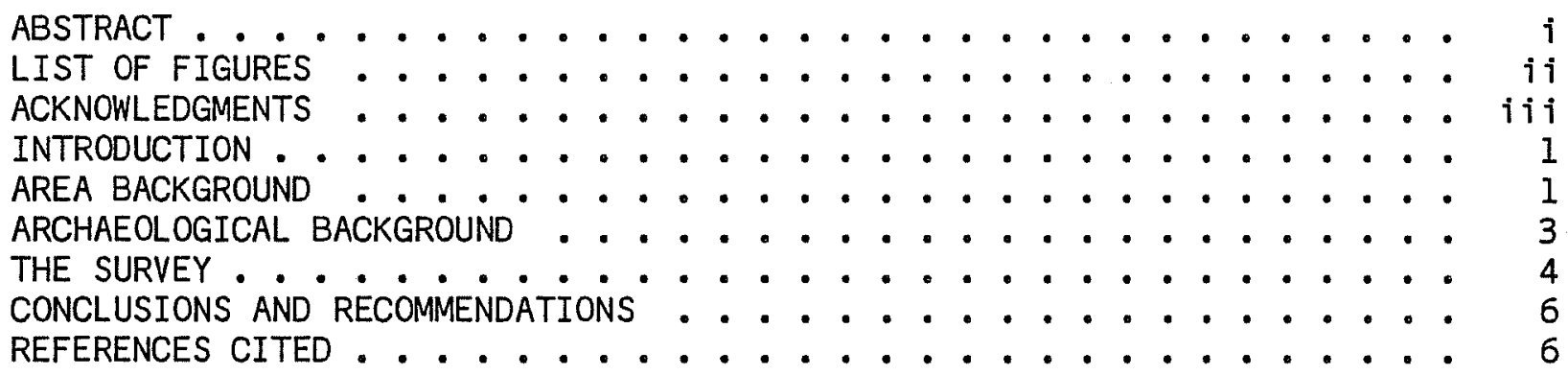

\section{LIST OF FIGURES}

1. Location of Converse City Park Survey Area and Site 41 BX 698 . . . 2

2. Plat of Converse City Park and Location of Site 41 BX 698 . . . . . 5 


\section{ACKNOWLEDGMENTS}

I am grateful to a number of people who helped expedite the field work. Jimmy Mitche11, a resident of Converse, provided information and insight on conserving sites in the area. Mrs. Joanne Von Muldau was very supportive of the project. The preparation of this report was aided by Mary Lou El 1 is, Sharon Quirk, Kelly Scott, and Ann Young. I would also like to thank Joan Petty for her help in the field. 



\section{INTRODUCTION}

During March 3-4, 1986, the Center for Archaeological Research (CAR), The University of Texas at San Antonio (UTSA), conducted an archaeological survey of the Converse City Park, located on the southwest side of Converse in Bexar County, Texas.

The survey was done under contract between the CAR-UTSA and the City of Converse (1etter received February 6, 1986). The survey was requested as part of the requirements for the funding of the park's development. This archaeological field survey complies with the Texas Antiquities Code, the Nationa 1 Historic Preservation Act of 1966, the Nationa 1 Environmenta 1 Policy Act of 1969 (NEPA), and Executive Order 11593.

The field work was conducted by Ralph Snavely, CAR staff archaeologist, under the supervision of Thomas R. Hester, CAR director.

The main objectives of the survey were: (1) to determine by surface examination if archaeological cultural resources are present within the study area; and (2) to form recommendations for any further work needed in order to determine site(s) potential eligibility for nomination to the National Register of Historic Places.

\section{AREA BACKGROUND}

The survey area is in the southwest portion of Converse in Bexar County, Texas. Converse City Park is 1 ocated $0.5 \mathrm{~km}$ north of the intersection of State Highway 78 and Martinez Creek. Converse is in the northeastern part of Bexar County, Texas (Fig. 1).

The drainage systems associated with the survey area are Martinez Creek, within the immediate survey area, and Cibolo Creek which is approximately $5 \mathrm{~km}$ to the northeast. There is less than 30. feet of topographic relief occurring within the study area. This may be the result of clearing, plowing, and other 1 and modifying agricultural practices.

The climate of Bexar County is subtropical, with mild winters and hot summers. The daily maximum and minimum temperature averages are $79.2^{\circ} \mathrm{F}$ and $53.1^{\circ} \mathrm{F}$, respectively. Precipitation is usually even ly distributed throughout the year, averaging 27.84 inches per year (Taylor, Hailey, and Richmond $1966)$.

Bexar County 1 ies in the transition zone between the southern 1 imits of the Edwards Plateau and the northern rim of the South Texas Coastal Plain. The water drainage pattern in Bexar County is in a south to southeastward direction. The major streams of the county are Cibolo Creek, Leon Creek, Medina River, San Antonio River, and Salado Creek. The northern half of the county is characterized by prominent eroding 1 imestone uplifts and a thin, calcareous soil. The southern half of the county is characterized by gently rolling hills and a deep sandy loam soil (Taylor, Hailey, and Richmond 1966). 


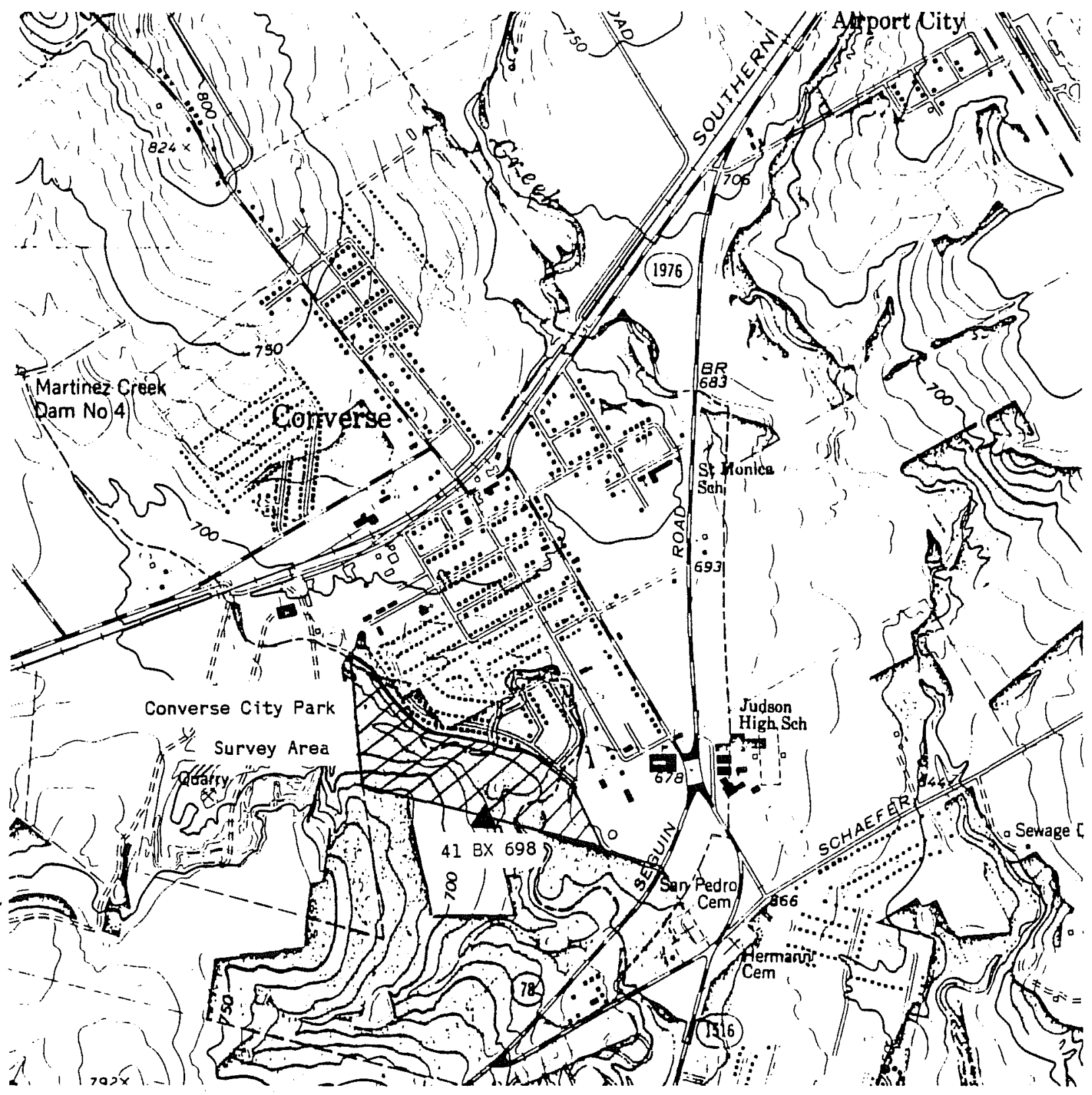

Figure 1. Location of Converse City Park Survey Area and Site 41 BX 698. 
A detailed study of the flora and fauna of the survey area is beyond the scope of this report. The study area falls within portions of three biotic provinces as discussed by Blair (1950): the Balconian, Texan, and Tamaulipan. Additional information on the flora and fauna may be obtained from Blair (1950), Davis (1974), and Gerst1e, Kel1y, and Assad (1978).

Within the study area there are three distinct soil associations: Houston Black-Houston (deep clayey soils over calcareous clay), Venus-Frio-Trinity (deep, calcareous soils on bottomlands and lower terrace), and LewisvilleHouston Black (terrace associated, deep, calcareous soils in old alluvium). These three soil associations are often mixed, a complication resulting from erosion and redeposition of alluvium (for more detail refer to Taylor, Hailey, and Richmond 1966).

\section{ARCHAEOLOGICAL BACKGROUND}

More than 650 archaeological sites have been recorded in Bexar County, making it one of the most archaeological1y studied counties in Texas. Most of these sites have only been investigated on the preliminary survey level, but a few authors have studied the archaeology of the area on a county-wide scale. Woolford (1935) produced a general analysis of sites in this area, and in 1972 Fawcett (1972) reviewed al1 prior work in Bexar County. A number of studies conducted by the CAR-UTSA have contributed a vast amount of archaeological data. These investigations include Hester et a1. (1974), Smith and McDonald (1975), Black and McGraw (1985), and Gerstle, Kel1y, and Assad (1978).

Sites of major archaeological significance in Bexar County include 41 BX 1 , the 01 mos Dam site (Lukowski n.d.); 41 BX 17, the Granberg site; 41 BX 22, the Rodgers site; 41 BX 228, the Panther Springs site (B1ack and McGraw 1985); 41 BX 228, the Walker Ranch site; and 41 BX 229, the St. Mary's Hal1 site (Hester 1978). These sites represent occupations of a temporal variety from the $\mathrm{Paleo-Indian}$ through the Historic Indian periods of south-central Texas. A background on the archaeology of south-central Texas is provided in Hester (1980) and B1 ack and McGraw (1985).

A review of previous archaeological research illustrates several types of prehistoric sites which may be found in Bexar County. The site types of this area and associated cultural remains are described by Fox (1977:1) as follows:

Long-term or traditionaliy revisited occupation sites (campsites) are characterized by deep deposits containing stone tools, projectile points and the debris resulting from their manufacture and repair. Fragments of animal bones, snails and mussel shells wi11 often be present, along with scattered 1 imestone hearth stones. Temporary camping sites (related to short-term hunting or food gathering activities) are reflected by a thin scatter of chert flakes, hearth stones and tools in a 1 imited area. Occasionally these temporary campsites occur in sheltered overhangs in the b 1 uffs of northern Bexar County. streams. Quarries and workshop areas occur near the outcrops of chert, usual1y in areas of exposed 
1 imestone. Such sites are numerous in the northern part of the county. These sites are characterized by numerous nodules of chert and debris resulting from the primary process of tool manufacture.

Cibolo Creek, a major drainage in northeastern Bexar County, has attracted prehistoric Indians and the animals they hunted as early as the Paleo-Indian period. Although numerous prehistoric sites dating from Paleo-Indian through the Late Archaic periods have been reported al ong the upper Cibolo Creek (Gerstle, Kel 1y, and Assad 1978), the archaeology of the lower Cibolo Creek and Martinez Creek is not as well known. There are no recorded sites in the immediate vicinity of the survey area.

\section{THE SURVEY}

The field survey consisted of a series of transects, approximately $20 \mathrm{~m}$ apart throughout the entire study area of 25 acres. The survey area is dissected by Martinez Creek. The majority of the park is within the Martinez Creek floodplain. A smal1 percentage (approximately 35\%) of the City Park 1 and is located above the modern floodplain. A USGS topographic map (Schertz Quadrangle) was consulted to establish the general outlay of the terrain.

Observations were recorded on the occurrence, density, and location of prehistoric remains. Only diagnostic or otherwise significant artifacts were to be collected for analysis. The location of prehistoric remains (1ithic debitage) was plotted on a map of the development area.

The study area 1 imits were defined by roads and fences clearly demarcating the property 1 ines. The existing profiles of the creek bank, erosion areas, roadbeds, and other vegetation free areas were inspected for cultural remains. In addition, smal1 probes approximately $10 \mathrm{~cm}$ in depth, were made in an area suspected of containing subsurface cultural deposits.

A prehistoric site was located in the southern center part of the survey area evidenced by 1 ithic debris scattered on the ground surface (Fig. 2). Further inspection of the area revealed several primary flakes and one core. No dart points, stone tools, or diagnostics were observed.

The core which was observed was of a good quality chert, commonly found in Uvalde Gravels. Natural deposits of these chert-bearing gravels occur throughout the al1uvial floodplain of Martinez Creek.

The surface lithic scatter consists of mostly primary flakes with a few secondary flakes present. This thin 1 ithic scatter may represent a prehistoric chert reduction area.

A series of six trowel probes paralleling the western property 1 ine in the area of the site was executed. Each test was approximately $10 \mathrm{~cm}^{2}$ and $10-$ $15 \mathrm{~cm}$ in depth. No cultural materials were recovered from these probes. The site was recorded, and a permanent state archaeological site designation has been assigned (4l BX 698) by the Texas Archeological Research Laboratory in Austin. Photographs were taken and are on file at the CAR. 
This page has been

redacted because it

contains restricted

information. 


\section{CONCLUSIONS AND RECOMMENDATIONS}

During the survey, the entire Converse City Park area was carefully examined. One location with a small amount of cultural materials on the ground surface was recorded as site 41 BX 698. The site contains a 1 ight 1 ithic scatter; it is possible that this is the edge of a site which extends south outside of the present survey area. No further work is recommended at site $41 \mathrm{BX} 698$. However, should cultural resources be uncovered during any 1 and modifying development, the Texas Historical Commission should be notified.

\section{REFERENCES CITED}

Black, S. L. and A. J. McGraw

1985 The Panther Springs Creek Site: Cultural Change and Continuity Within the Upper Salado Creek Watershed, SouthCentral, Texas. Center for Archaeological Research, The University of Texas at San Antonio, Archaeological Survey Report 100.

B 1 air, W. F.

1950 The Biotic Provinces of Texas. The Texas Journal of Science I(2): 93-116.

Davis, W. B.

1974 The Mamma 15 of Texas. Texas Parks and Wild 1 ife Department, Bul 1 etin 41.

Fawcett, W. B., Jr.

1972 The Prehistory of Bexar County: A Study of Previous Work in South-Central Texas. Bulletin, Lower Plains Archaeological Society 2 (for 1971):23-44.

Fox, A. A.

1977 An Archaeological Assessment of the San Antonio 201 Wastewater Treatment Project. Center for Archaeological Research. The University of Texas at San Antonio, Archaeological Survey Report 41.

Gerst7e, A., T. C. Kelty, and C. Assad

1978 The Fort Sam Houston Project: An Archaeological and Historical Assessment. Center for Archaeological Research. The University of Texas at San Antonio, Archaeological Survey Report 40. 
Hester, T. R.

1978 Early Human Occupations in South Central and Southwestern Texas: Preliminary Papers on the Baker Cave and St. Mary's Hal1 Sites. Center for Archaeological Research, The University of Texas at San Antonio.

Hester, T. R.

1980 Digging Into South Texas Prehistory. Corona Publishing Company, San Antonio.

Hester, T. R., F. A. Bass, Jr., A. A. Fox, T. C. Kel1y, M. F. Chadderdon, and E. S. Harris

1974 Archaeological Survey of Areas Proposed for Modification in the Salado Creek Watershed, Bexar County, Texas. Center for Archaeological Research. The University of Texas at San Antonio, Archaeological Survey Report 3.

Lukowski, P.

n.d. Archaeological Investigations at 41 BX 1, Bexar County, Texas. Center for Archaeological Research, The University of Texas at San Antonio, Archaeological Survey Report 135 (in preparation).

Smith, H. P., Jr. and K. McDonald

1975 An Archaeological Survey of Friedrich Park, Bexar County, Texas. Center for Archaeological Research. The University of Texas at San Antonio, Archaeological Survey Report 12.

Taylor, F. B., R. B. Hailey, and B. L. Richmond

1966 Soit Survey of Bexar County, Texas. U.S. Department of Agriculture, Soil Conservation Service, Series 1962:12.

Woolford, S. W.

1935 Types of Archeological Sites in Bexar County, Texas. Witte Memorial Museum, Archeological Bul1etin 4. 
